\title{
SEVEN DECADES OF STUDIES WITH ASOPINAE PREDATORS IN BRAZIL
} (1933•-○2014)

\section{SETE DÉCADAS DE ESTUDOS COM ASOPINAE PREDADORES NO BRASIL (1933•-○2014)}

\author{
Evaldo Martins PIRES ${ }^{1}$; Marcus Alvarenga SOARES ${ }^{2}$; Roberta Martins NOGUEIRA ${ }^{1}$, \\ José Cola ZANUNCIO ${ }^{3}$; Paulo Sergio Andrade MOREIRA ${ }^{1}$; Marco Antonio de OLIVEIRA ${ }^{3}$ \\ 1. Professores Doutores na Universidade Federal de Mato Grosso, Sinop, Mato Grosso, MT, Brasil. evaldo.pires@gmail.com; 2. \\ Professor Doutor na Universidade Federal dos Vales do Jequitinhonha e Mucuri, Diamantina, MG, Brasil; 3. Professores Doutores na \\ Universidade Federal de Viçosa, Viçosa, MG, Brasil.
}

\begin{abstract}
Studies of Asopinae predators in Brazil were initiated in the 1930's, focusing on the use of these insects in biological control programs. However, the beginning of a period of major contributions to the knowledge on Asopinae predators started in the year 1986, with the release of the first research results, in the Proceedings of the X Brazilian Congress of Entomology in Maceió, Alagoas, Brazil. In 1991 the first scientific paper was published on the predator Podisus connexivus Bergroth [= Podisus nigrispinus (Dallas)] (Hemiptera: Pentatomidae), with study of the biological parameters of this predator for alternative feeding of the caterpillars Bombyx mori Linnaeus (Lepidoptera: Bombycidae) and larvae Musca domestica (Linnaeus) (Diptera: Muscidae). The first master thesis studying Asopinae predators in Brazil was defended in 1990 at the Federal University of Lavras, which focused was on biology and predatory capacity of Podisus nigrolimbatus [= Brontocoris nigrolimbatus = Brontocoris tabidus] and Podisus connexivus [= Podisus nigrispinus] in the laboratory. Throughout all these years of research and investigations, advances with Asopinae predators occurred in several fields that resulted in a better understanding of these insects, making them an effective tool for controlling insect pests in the agriculture and forestry sectors.
\end{abstract}

KEYWORDS: Biology. Biochemistry. Ecology. Mass rearing. Taxonomy. Toxicology.

\section{INTRODUCTION}

Stink bugs of the subfamily Asopinae are highlighted in biological control programs of agricultural and forest pests because they are generalist predators, feeding on a large number of insects from different orders. Due to characteristics including natural occurrence, aggressiveness and voracity, these insects have been widely studied in Brazil for Integrated Pest Management (IPM) programs. These natural enemies contribute to the population balance of phytophagous insects, mainly defoliating caterpillars, permitting reduced use of pesticides in agricultural systems and planted forests, and consequently the conservation of the environment (DE BORTOLI et al., 2011; TORRES et al., 2006a; VACARI et al., 2007; 2004).

Studies using Asopinae predators in Brazil were initiated in the 1930 's, where the first results of a Brazilian study were published in the paper entitled "Contribution to the biological study of three pentatomids and potential use of these insects to control harmful species" (SILVA, 1933). This article was published in the journal "O Campo" (The Field), Rio de Janeiro, by the researcher Aristóteles Godofredo de Araujo e Silva who studied the biological parameters of the predator Asopinae Oplomus (Catostyrax) catena (Drury) feeding on the caterpillar Actinote pellenea (Acraeidae) on bonesets (Eupatorium sp.); and patetieus (sic) (Eupodisus) mellipes (Bergroth) and Alcaeorhynchus grandis (Dallas) preying on the caterpillar Dione juno (Heliconiidae) in passion fruit, with a detailed description of the morphology of these insects.

In 1940, Professor Ângelo Moreira da Costa Lima reported that Asopinae predators may be considered useful for agriculture, since they generally prey on eggs, larvae and adults of pest insects. The best known species attack larvae of Lepidoptera and eggs, larvae and even adult beetles of the superfamily Chrysomeloidea (COSTA LIMA, 1940).

After these first reports, Asopinae predators were targeted for study by a group of taxonomists who began a painstaking investigative Systematic and Taxonomy study of the species of this group in Brazil. In 1951, the researcher Romeu de Tella published the second article on Asopinae preditors by a Brazilian in the Journal Bragantia, entitled "Bionomic data of a predatory stinkbug", in which the morphological description was presented for the life cycle phases of Tynacantha marginata (Dallas) (Heteroptera: Pentatomidae: Asopinae) (TELLA, 1951). 
With the exception of the first article published with Asopinae, whose main focus was to study the biology of predators, including A. grandis, and which despite this presents an important morphological description of this insect, all publications in nearly five decades of research considered taxonomy of great importance for the continuation of studies in other segments.

In 1976, for the first time in the X Brazilian Congress on Entomology in Maceió, Alagoas, Brazil, results were presented of a research entitled "Biology of Podisus sp. (Pentatomidae: Asopinae)" (MORAES et al., 1976).

In 1990 the first Master's dissertation was defended on the theme "Biology and predatory capacity of Podisus nigrolimbatus Spinola, 1832 and Podisus connexius Bergroth, 1861 (Hemiptera: Pentatomidae: Asopinae) in laboratory conditions", developed at the Federal University of Lavras (UFLA), which focused on predatory stinkbugs (FERNANDES, 1990). The species studied are today referred to as Brontocoris tabidus and Podisus nigrispinus, respectively.

In 1974, at the Luiz de Queiroz School of Agriculture (Escola Superior de Agricultura Luiz de Queiroz - ESALQ) the first doctoral thesis was defended entitled "Biology of Thyrinteina arnobia (Stoll) (Lepidoptera, Geometridae) and observations on the occurrence of natural enemies", which evaluated the predator Asopinae (Alcaeorrhynchus grandis). However, the focus of this thesis was not the stinkbug, but the caterpillar Thyrinteina arnobia (Lepidoptera: Geometridae) (BERTI FILHO, 1974). In 1995, at the Federal University of Viçosa (UFV), the first doctoral thesis was defended which dealt specifically with Asopinae predators whose theme was "Artificial diet for Podisus nigrispinus (Dallas) and influence on its ability for predation of Anticarsia gemmatalis Hubner" (SAAVEDRA, 1995).

Through years of research and investigations, advances with Asopinae predators have resulted in various studies of biology and plant health such as: increasing the number of species reported (THOMAS, 1992), definition and presentation of the main species for biological control programs (PIRES et al., 2009a; THOMAS, 1992), increase in the number of institutions collaborating in this line of research (Federal University of Viçosa - UFV, Federal University of Lavras - UFLA, Federal University of Mato Grosso - UFMT, Federal University of Vales do Jequitinhonha and Mucuri - UFVJM, Federal University of Paraíba - UFPB, Federal University of Grande Dourados - UFGD, Federal University of
Rio Grande do Sul - UFRGS, Federal University of Minas Gerais - UFMG, Federal University of Pará UFPA, Federal Rural Univeristy of Pernambuco UFRPE and EMBRAPA), evolution of equipment for mass rearing (ZANUNCIO et al., 1994a) and techniques and form of management (MOLINARUGAMA et al., 1998; PELÚZIO, 2012; PIRES et al., 2006; ZANUNCIO et al., 1994a), accommodation and ambience (MEDEIROS et al., 2003; SANTOS et al., 2005), physiology and internal and external morphology (AZEVEDO et al., 2007; GUEDES et al., 2007; LEMOS et al., 2006; 2005a;b;c; SOARES et al., 2011; SÁ et al., 2013), studies on sensory and (ALDRICH et al., 1997; CORACINI et al., 1999; TORRES et al., 1997a) behavioral aspects (CARVALHO et al., 1995; 1994; FERREIRA et al., 2008; LEMOS et al., 2005d; PIRES et al., 2010a; 2009b; SAAVEDRA et al., 1997; SILVA et al., 2012; VIVIAN et al., 2002), toxicology, with focus on studies on selectivity of insecticides (BATALHA et al., 1995; CASTRO et al., 2013; 2012; GONRING et al., 2003; GUEDES et al., 1992; PICANÇO et al., 1997; SUINAGA et al., 1996; ZANUNCIO et al., 2003) and herbicides (CAMILO et al., 2012; MENEZES et al., 2012), implementation of Asopinae predators in biological control programs in genetically modified plants, tolerant to glyphosate (LACERDA, 2008), ability to associate predators with parasitoids and entomopathogenic organisms in the control of pests (CARVALHO et al., 2012; HOLTZ et al., 2006a; SOARES, 2010; TORRES; Ruberson, 2008), liberation of these natural enemies (NEVES et al., 2009; PIRES, 2010; TORRES et al., 2002) and breeding of individuals for mass rearing to increase the reproductive potential (PELÚZIO, 2012).

Stinkbugs predators, which are highlighted as biological control agents in Brazil, are of the genera Brontocoris and Podisus (Pentatomidae: Asopinae), most aggressive and encountered in practically the entire country. Besides species of these genera, Alcaeorrhychus, Supputius and Tynacantha have species with potential for control of agricultural and forest pests.

The Asopinae species most studied and recommended for biological control in IPM programs in Brazil are Alcaeorrhynchus grandis (Dallas), Brontocoris tabidus (Signoret), Podisus distinctus (Stal), Podisus nigrispinus (Dallas), Supputius cincticeps (Stal) and Tynacantha marginata (Dallas), highlighting P. nigrispinus due to its voracity and aggressiveness (De BORTOLI et al., 2011; VACARI et al., 2007; 2004; MENEZES et al., 2013). 
The advancement of studies with Asopinae predators in Brazil contributes to the understanding of various aspects related to these insects and makes them an efficient tool for the management of agricultural and forest pests. This study aimed to perform a literature review on Asopinae produced by Brazilian researchers over seven decades of scientific contributions.

\section{DEVELOPMENT}

The search and acquisition of publications was performed with aid of library searches of institutions including the Federal University of Mato Grosso, Federal University of Viçosa, Federal University of Lavras, Federal Rural University of Rio de Janeiro, Federal University of Rio de Janeiro (National Museum of the Federal University of Rio de Janeiro), Federal University of Paraná, Federal University of Rio Grande do Sul, Federal University of the Vales do Jequitinhonha and Mucuri, University of São Paulo, Library of Embrapa
Amazônia Oriental, National Agricultural Library, Library of the Oswaldo Cruz Institute, as well as the personal collection of Professor Dr. Jocélia Grazia (UFRGS).

\section{Historical contextualization}

Brazilian researchers have contributed to studies on Heteroptera: Asopinae over the last 70 years. Since 1933, 270 scientific papers were published with predatory stinkbugs. Of this total, 163 were published in Brazil journals and 107 in foreign journals, corresponding to 60.38 and $39.62 \%$, respectively (Figure 1).

This scientific production is mainly due to the efforts of researchers from Brazilian Federal Universities and Embrapa. The UFV is a Brazilian institution with great contribution to this line of research and is considered a great multiplier of these studies. This has been done directly with scientific production and training of researchers, now dispersed throughout Brazil and abroad, continuing studies on Asopinae.

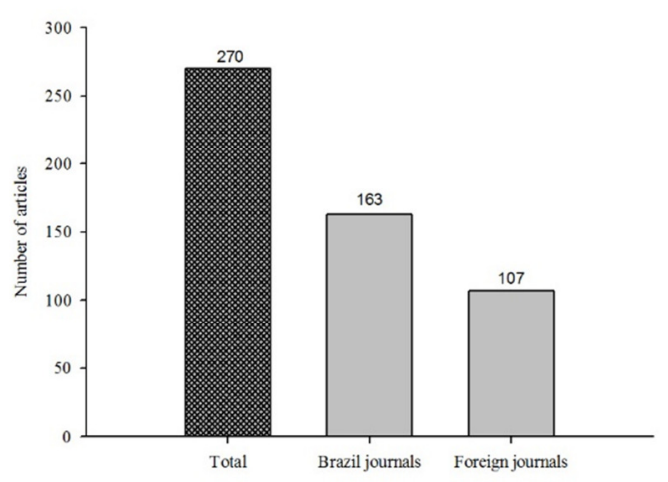

Figure 1. Total number and number of Brazilian and foreign journals in which articles were published by Brazilian researchers over seven decades of research with Asopinae predators.

The importance of Systematics and Taxonomy on the history of research with Asopinae in Brazil

The Systematics and Taxonomy of Asopinae is highlighted at the beginning of studies with these predators and for practically five decades contributed decisively to the establishment of this line of entomological research. With the exception of the first article (1933), all publications until 1982 were along these lines, and only in 1982 was the study published entitled "Bioecology of Podisus nigrolimbatus Spinola (Heteroptera: Pentatomidae), predator of Pyrrhalta luteola (Mülher) (Coleoptera: Chrysomelidae)" in an different from taxonomy
(ARTOLA et al., 1982). The scientific contribution provided by systematists and taxonomists totals 13 papers, corresponding to $4.81 \%$ of the scientific contribution with Asopinae produced by Brazilian researchers over these 70 years (Figure 2A). This line of research was fundamental for understanding this group of insects by identifying the main species occurring in Brazil (BUCKUP, 1961; 1960; 1952; COSTA LEITE, 1957; COSTA LIMA, 1940; GRAZIA et al., 1987; 1985; 1980; LIMA, 1948; SILVA, 1965; TELA, 1951). The knowledge generated was key to the development of applied studies, which were and continue to be developed. 

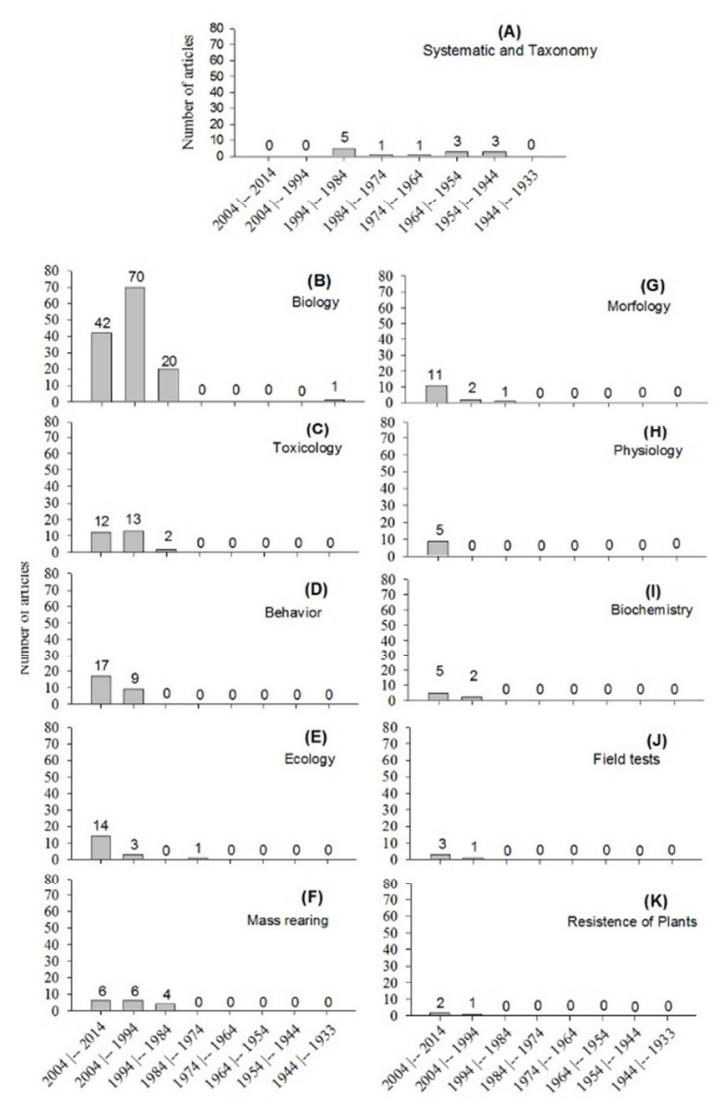

Figure 2. Retrospect per research area over 70 years of studies with Asopinae predators in Brazil.

\section{Scientific contributions in the field of biology (biological and reproductive parameters)}

Studies on the biology (biological and reproductive parameters) of Asopinae predators were the most numerous, totaling 133 publications over these 70 years of research and correspond to $49.26 \%$ of the scientific contribution (Figure 2). Of this total, only the article by SILVA (1933), a pioneer on these predators in Brazil, was not produced in the last three decades (1984•-01994; 1994•-O2004; 2004•-O2014) (Figure 2B). The biology of these predators was really developed after 1984.

Some publications in this area can be considered classics due to the relevance of their contributions. Among these, the works involving the use of artificial diets can be highlighted (Saavedra et al 2001; 1999; 1996; 1995; 1992a; 1992b), which were important for understanding the nutritional adequacy of predators produced on a large scale. Their focus was to obtain a food capable of substituting the natural and alternative preys, which makes rearing of the stinkbug predator an onerous process. Also in this line of study, a positive contribution was knowledge on the beneficial effects of using plant material (plant leaves) as a food supplement for these insects, which can improve the biological and reproductive parameters of these predators (ASSIS JR. et al., 1998; MOREIRA et al., 1997; OLIVEIRA et al., 2002).

The studies showing the effects of climate conditions on the biology of Asopinae also allowed for understanding the ideal temperature conditions, as well as the extreme limits (maximum and minimum) that compromise the reproduction and development of these insects. These studies may aid in the implementation of biological control programs with Asopinae, since thermal requirements can predict the unfeasibility of such programs in certain locations in Brazil and worldwide (DIDONET et al., 1995; MEDEIROS et al., 2004; 2003; SANTOS et al., 2005; TORRES et al., 1998).

The justification for this large number of publications in the field of biology of Asopinae may be explained by several factors, however, principally due to the fact that these predators have generalist feeding habits, which permitted the generation of large amounts of information in basic studies. The need to understand factors such as adequate food conditions (use and adequacy of natural, alternative and artificial diets and food 
supplements) resulted in performance improvements of mass rearing in the laboratory and in the field (PIRES et al., 2010a; SAAVEDRA et al., 1997; 1996; VACARI et al., 2007; ZANUNCIO et al., 2001; 1996; ZANUNCIO et al., 1993a; 1991).

\section{Scientific contributions in the field of Toxicology}

Research on the toxicology of insecticides, seeking to understand the effects of chemical compounds on Asopinae resulted in publication of 27 scientific articles by Brazilian researchers, corresponding to $10.00 \%$ of production on Asopinae in Brazil (Figure 2C). The first article published on this subject was in 1992, where the subject of the study was "Selectivity of the insecticides deltamethrin, fenvalerate and fenitrothion for Podisus connexivus Bergroth $[=P$. nigrispinus $]$ (Heteroptera: Pentatomidae)" (GUEDES et al., 1992).

From this work, the main segment of research sought to determine aspects associated with effects of insecticides on the predator (CASTRO et al., 2012; PEREIRA et al., 2009; PICANÇO et al., 1997; TORRES; RUBERSON, 2004; TORRES et al., 2003; 1999; ZANUNCIO et al., 2003; 1993b), which can be regarded as basic research, since from these results other studies with wider applicability were initiated. These include studies on selectivity of insecticides, which aim to understand compounds with toxicological effect on pests, but which preserve the natural enemy (GONRING et al., 2003; SUINAGA et al., 1996; TORRES, 2012; ZANUNCIO et al., 1998). This information contributed to the implementation of management tactics, such as chemical control associated with the use of Asopinae predators, which can increase efficiency for IPM in the agriculture and forestry sectors (BATALHA et al., 1995; CASTRO et al., 2013; 2012; GUEDES et al., 1992; PICANÇO et al., 1997; ZANUNCIO et al., 2003).

In this line of research, researchers confirmed the selectivity of insecticides by evaluating mortality or otherwise of non-insect predators. Moreover, they showed the ability of predators to develop and reproduce when submitted to sub-lethal doses of chemicals as one of the important milestones for toxicology research in Brazil (LEMOS et al., 2005c; MAGALHÃES et al., 2002; ZANUNCIO et al., 2013; ZANUNCIO et al., 2005). Hormesis, where a determined concentration of a chemical compound with insecticide characteristics promotes a positive responses in the biology of predators, was a big surprise to researchers in the area (ZANUNCIO et al. 2011b; ZANUNCIO et al. 2003).
The discovery that herbicides used in agroecosystems for weed control and which act on metabolic pathways that insects do not have could be toxic to natural enemies led to the need to test the selectivity of these compounds against Asopinae. Negative effects on the development, survival and reproduction of Asopinae predators exposed to commercial herbicide concentrations were reported (CAMILO et al., 2012; MENEZES et al., 2012). These studies led to a reflection on the need to align, through the selection of products less aggressive to natural enemies, Weed Management with IPM.

\section{Scientific contributions in the field of investigating behavioral aspects}

The main focus of this line of research was behavioral aspects of Asopinae predators, with the publication of 26 articles on these predators in Brazil, accounting for $9.63 \%$ of scientific production (Figure 2D). Dissemination of the results of these surveys was initiated in 1994 with publication of the article entitled "Pace of mating behavior and sexual activity of Podisus connexivus Bergroth $[=P$. nigrispinus $]$ (Heteroptera: Pentatomidae: Asopinae) (CARVALHO et al., 1994a).

From these works, studies on this subject have shown the attack strategy of Asopinae predators on pests, defense mechanisms of herbivores in predation conditions and acceptance of food in the form of natural or alternative prey or artificial diets (CARVALHO et al., 1995; 1994a; CORACINI et al., 1999; FERREIRA et al., 2008; GROSMAN et al., 2005; LEMOS et al., 2005d; PIRES et al., 2009b; SAAVEDRA et al., 1997; SILVA et al., 2012; SOARES et al., 2009; VIVIAN et al., 2002). This helped to understand the occurrence of cannibalism in mass rearing and reduced losses caused by this behavior (PIRES et al., 2010a).

Observations on the behavior of courtship and copulation helped to understand aspects associated with the acceptance or rejection by his co-specific female (CARVALHO et al., 1994; MENDONÇA et al., 1997) and provided information on the mating dynamics of these insects. Thus, it was discovered that the reproductive success of $P$. nigrispinus is associated with conducting multiple and lasting copulations (RODRIGUES et al., 2008; SOARES et al., 2011).

Other papers on this subject provide detailed information on the defense of prey against the predator (PIRES et al., 2009b; SOARES et al., 2009; ZANUNCIO et al., 2008) and that temperature influences the predation ability of 
Asopinae (AZEVEDO et al., 1999a; b). Others evaluated the behavior of searching for prey (GROSMAN et al., 2005), attack and predation (FERREIRA et al., 2008; LEMOS et al., 2005d; VACARI et al., 2012) and feeding in function of prey density (OLIVEIRA et al., 2008; VIVIAN et al., 2002). This improved the conditions for delivery of food in mass rearing, where excess food can impair nutrition of predators because they present extra-oral digestion and the beginning of food intake occurs sometime after attack of the prey. Thus, excessive supply of food causes the insect, which has predatory instincts, to constantly attack the moving prey so that it spends too much time performing this activity without eating properly.

\section{Scientific contributions in the Ecology field}

Studies on ecological interactions of Asopinae contributed to the production of 18 scientific articles throughout these 70 years of studies in Brazil, corresponding to $6.67 \%$ of production (Figure 2E).

The first article on ecology published by a Brazilian researcher was in 1982, entitled "Bioecology of Podisus nigrolimbatus Spinola (Heteroptera: Pentatomidae) predator of Pyrrhalta luteola (Mülher) (Coleoptera: Chrysomelidae)". This study demonstrated the predation ability of this species on a chrysomelid (ARTOLA et al., 1982). From these results, other studies contributed to the understanding of issues such as the interaction of Asopinae eggs with parasitoid wasps (ZANUNCIO et al., 2000), which may hinder the implementation of biological control programs using these natural enemies. The predator studied is today known as Brontocoris tabidus. On the other hand, association of the Asopinae predator with a parasitoid of the genus Trichogramma showed satisfactory results. There was no emergence of Trichogramma adults, but the viability of eggs of Asopinae was not affected, therefore the associated use of these two natural enemies may be recommended (HOLTZ et al., 2006a). The interaction of $P$. nigrispinus with the parasitoid Palmistichus elaeisis (Delvare; LaSalle) (Hymenoptera: Eulophidae) was also observed in the laboratory, with results indicating that this predator is able to recognize, through chemical and morphological signals, previously parasitized prey and avoid them, reducing intraguild predation rates in the field (SOARES, 2010).

Other ecological studies were performed with life tables that sought to provide information on the population dynamics of a species, highlighting issues such as mortality rates and estimates of breeding in age intervals of a population under specific conditions (MEDEIROS et al., 2003b; MOREIRA et al., 1995; VACARI et al., 2009; ZANUNCIO et al., 2006).

Studies on the response of Asopinae predators reared in the laboratory with alternative prey (Tenebrio molitor pupae) led researchers to question the success of this natural enemy in the field, since it could lose the ability to locate its natural prey. This led to the development of studies to verify localization capabilities of these prey in the field. Results showed that Asopinae expressed greater preference to move in the direction of eucalyptus plants injured by the attack of Thyrinteina arnobia in relation to those semi-injured (HOLTZ et al., 2006b).

The relationship of Asopinae predators with bacteria was also studied. The bacterium Bacillus thuringiensis, used in transgenic cotton plants, was expressed in the predator Asopinae which fed on the caterpillar that attacked the plant, but caused no negative effect on the predator (TORRES; RUBERSON, 2008; TORRES et al., 2006b). However, long-term effects of this interaction indicated decrease in offspring of females of $P$. nigrispinus over generations, resulting in a lower population growth rate for those that daily consumed the infected larvae (GOULART et al., 2010). Effects of the fungi Metarhizium anisopliae (Metsch.) Sorok. and Beauveria bassiana (Bals.) Vuill., on the Asopinae predator were satisfactory and they can be used together. Nymphs of the predator had higher mortality when exposed to $M$. anisopliae, but adults were not affected (FRANÇA et al., 2006).

With regard to the host plant, the predator B. tabidus showed no preference among the tested plants (Amaranthus lividus, Gossypium hirsutum and Phaseolus vulgaris), which favors its occurrence in different ecosystems using plants as a source of water and possibly nutrients (COELHO et al., 2009).

\section{Scientific contributions in Mass Rearing studies}

Contributions to the knowledge and conduct of mass rearing of Asopinae predators throughout these 70 years of research in Brazil was presented in a total of 16 articles published by Brazilian researchers, corresponding to $5.93 \%$ of publications (Figure 2F). The first article published on this subject was in 1992, whose theme was "Methods for rearing of Hemiptera predators of caterpillars" (ZANUNCIO et al., 1992).

Studies on mass rearing methods have permitted improved management of these insects (DE BORTOLI et al., 2011; PIRES et al., 2006; 
TORRES et al., 2006a; 1997b; ZANUNCIO et al., 2011a; 1994a; 1994b) and development of equipment and techniques for improved production of these natural enemies with higher quality and lower cost (OLIVEIRA et al., 2001; OTUKA et al., 2006; PIRES et al., 2009a; ZANUNCIO et al., 1994a).

Currently, companies operating in the forest sector, mainly with Eucalyptus spp., use Asopinae predators as biological control agents against defoliating caterpillars, which can aid in reducing mega populations of these pests and also reduce the use of insecticides.

The advances acquired from studies in this sector have improved quality and increased production of these insects in the laboratory for subsequent release during periods of Lepidoptera defoliator outbreaks. The company Vallourec Florestal annually produces about 500,000 adult predators of the species Podisus nigrispinus in conditions of release, for use in their plantations, which can control or even prevent outbreaks of these pests.

\section{Scientific contributions in the field of Morphology}

Studies on the morphology of Asopinae predators resulted in the publication of 14 scientific articles produced by Brazilian researchers, corresponding to $5.19 \%$ of scientific production with Asopinae (Figure 2G). The first work in this line of study was published in 1994, entitled "Morphological characterization of the sex pheromone gland of the Neotropical predator Podisus nigrispinus (Dallas)" (CARVALHO et al., 1994b).

From this research, the studies on this subject allowed for understanding details on the effects of the diet (CUNHA et al., 2012; LEMOS et al., 2010a; b; 2005a; b; MOREIRA et al., 1996) and the methods of its administration (FIALHO et al., 2009), affecting the internal morphology of these insects. Studies on the possibility of mating (copulation duration and successive copulations) provide morphological changes of the spermatheca and ducts showed that the spermatheca of Asopinae presented elastic characteristics and that the ducts were not affected ("swollen") after $30 \mathrm{~min}$ copulations (RODRIGUES et al., 2008). Morphology of the spermatozoa of Asopinae was observed and results may help systematists and taxonomists identify insects of this group (ARAÚJO et al., 2011).

\section{Scientific contributions in the field of Physiology}

Studies on physiological issues of Asopinae resulted in publication of nine scientific articles by Brazilian researchers representing $3.33 \%$ of production during these 70 years of research (Figure $2 \mathrm{H})$. The first results published in this line of research occurred in the last decade (2004•-○2014), in 2004, with the work entitled "Weight gain of the predator Podisus distinctus (Heteroptera: Pentatomidae) in combinations with the prey Tenebrio molitor (Coleoptera: Tenebrionidae) y Musca domestica (Diptera: Muscidae)", where the researchers verified weight gain of the predator Asopinae in function of different combinations of alternative prey (MATOS-NETO et al., 2004). In this line of research, other studies have shown that the type of diet is an important nutritional factor to increase the body weight of Asopinae (LEMOS et al., 2009a; b).

Other studies has shown that the physiological response of Asopinae predators, through weight gain and rate of consumption relative to the cotton bollworm Alabama argillacea (Hübner) (Lepidoptera: Noctuidae), is inversely proportional to the amount of food offered (PEREIRA et al., 2008).

Alterations in the reproductive structures of males and females of $B$. tadidus were also observed in insects of different ages and diets, showing that those ingesting plants showed morphologic changes in the reproductive tract (LEMOS et al., 2011; 2010c).

\section{Scientific contributions in the field of Biochemistry}

Biochemistry fills a large gap and contributes substantially to the knowledge generated by research with Asopinae predators. This line of research further aids in clarifying questions since the conclusions of several studies showed the need for further clarification. Studies involving biochemistry associated with predatory stinkbugs resulted in the publication of seven articles by Brazilian researchers over the 70 years, corresponding to $2.59 \%$ of production (Figure 2I). The first article published on this subject was in 1997, entitled "Extract of the pheromone gland in attracting and stimulation of feeding of Podisus nigrispinus (Dallas) and Supputius cincticeps (Stal)", where the effect of the extract from dorsalabdominal glands, producers of sex pheromone of Podisus nigrispinus (Dallas) and Supputius cincticeps (Stal) (Heteroptera: Pentatomidae), was observed when added to artificial diet as an attractant and feeding stimulant (TORRES et al., 1997a). 
In this line of research, other studies have characterized the enzyme pattern of the content of salivary glands and the midgut of the predator Brontocoris tabidus, indicating that this insect may be considered an obligate zoophytophagous species (AZEVEDO et al., 2007; GUEDES et al., 2007; OLIVEIRA et al., 2006). Regarding the same subject, other studies have shown that Asopinae predators present a "standard" enzyme in the salivary gland in function of the feeding behavior. The presence of pectinase can be observed in phytophagous species, phospholipase and trypisin as indicators of insects adapted to predation, and amylase and peptidase for omnivorous insects (phytophagous and predators) (TORRES; BOYD JR., 2009).

A study with the predator $P$. nigrispinus showed that its enzymes differ along the anterior, middle and posterior regions of the midgut (FIALHO et al., 2013).

\section{Scientific contributions in the field investigating Field Tests}

Field tests resulted in the production of four articles with Asopinae by Brazilian researchers, corresponding to $1.48 \%$ of scientific production (Figure 2J).

The first study published was "Field tests of predaceous pentatomid pheromones and semiochemistry of Podisus and Supputius species (Hemiptera: Pentatomidae: Asopinae)" (ALDRICH et al., 1997).

Other studies have been performed to verify the dispersion ability of nymphs of the predator $P$. nigrispinus in greenhouses (TORRES et al., 2002); and of adults with sliced or intact wings, seeking to understand the dispersion ability and effect of these conditions on the number of eggs per female of the insects (NEVES et al., 2009).

Pre-release strategies can provide insects used in the field with a faster response in foraging activity. Some care must be taken with respect to this period, since long periods without feeding can cause losses in mass rearing by cannibalism (PIRES et al., 2010a).

\section{Scientific contributions in the field investigating Resistance of Plants}

Studies focusing on understanding the mechanisms that give the plant the ability to defend itself (plant resistance), with Asopinae predators involved in this interaction, resulted in the production of three scientific articles by Brazilian researchers, corresponding to $1.11 \%$ of contributions in these 70 years of research (Figure $2 \mathrm{~K})$.

The first article published on this line of research was in 2000 with the theme "Tritrophic interaction between Podisus nigrispinus (Dallas) (Heteroptera: Pentatomidae), Eucalyptus and caterpillars of Thyrinteina arnobia (Stoll) (Lepidoptera: Geometridae): I- visitation". In this work it was found that the presence of caterpillars on the plant resulted in a greater number of visits by the predator, which may be due to release of kairomones in interaction of the host plant with the herbivore (CAVALCANTI et al., 2000).

After this study, Brazilian researchers focused on studies regarding the response of the predator Asopinae to the plant defense induced by the herbivore (HOLTZ et al., 2008), and in studies on antibiosis showed that the predator is not fully adapted to the exotic host plant, as demonstrated in its biological and reproductive characteristics (HOLTZ et al., 2010).

\section{CONCLUSIONS}

In the decades of 1994-2004 and 20042014, numerous lines of study with Asopinae were highlighted involving various segments.

The importance of these two decades may be due to an increased number of researchers, multiplying forces and therefore increasing the number of publications on Asopinae. Technological development of equipment and techniques is another factor related to these advances, by allowing better investigative and thorough conditions in the studies. Equipment such as high-precision microscopes, scanning electron microscopy, olfactometers, chromatographs, microtomes, etc., along with easily and rapid access to the latest technologies through the global network of computers, has contributed to constant improvement in quality of the research and permitted that results are accessible to scholars and professionals.

Even with the many years of research, predatory stinkbugs of the subfamily Asopinae appear to be the most well studied, especially regarding field research, including dynamic dispersion, migration and foraging of these insects, and the expanded use of these predators in the biological control of agricultural and forestry pests.

\section{ACKNOWLEDGEMENTS}

To the librarian services of the following institutions: UFMT, UFV, UFLA UFRRJ, UFRJ (MNRJ), UFPR, UFRGS, UFVJM, USP, Embrapa 
Amazônia Oriental, National Agricultural Library and Library of the Oswaldo Cruz Institute. Also to
PIRES, E. M. et al.

those who have always provided the inspiration to present what nature has allowed us to elucidate.

RESUMO: Estudos dos predadores Asopinae no Brasil foram iniciados na década de 1930 focando o uso desses insetos em programas de controle biológico. Entretanto, o início de um período de grandes contribuições sobre o conhecimento de predadores Asopinae iniciou-se a partir do ano de 1986, com a divulgação do primeiro resultado de pesquisa, nos Anais do X Congresso Brasileiro de Entomologia em Maceió, Alagoas. Em 1991, foi publicado o primeiro artigo científico sobre o predador Podisus connexivus Bergroth, 1891 [= Podisus nigrispinus (Dallas, 1851)] (Hemiptera: Pentatomidae), com o estudo dos parâmetros biológicos desse predador em alimentação alternada de lagartas de Bombyx mori Linnaeus, 1758 (Lepidoptera: Bombycidae) e larvas de Musca domestica (Linnaeus, 1758) (Diptera: Muscidae). A primeira dissertação de mestrado com predadores Asopinae no Brasil, foi defendida em 1990, na Universidade Federal de Lavras, onde o foco foi a biologia e a capacidade predatória de Podisus nigrolimbatus $[=$ Brontocoris nigrolimbatus $=$ Brontocoris tabidus] e Podisus connexivus [= P. nigrispinus] em laboratório. Ao longo de todos esses anos de investigações, os avanços com predadores Asopinae ocorreram em vários ramos que resultaram em um melhor entendimento desses insetos, tornando-os uma eficiente ferramenta no controle de insetos pragas nos setores agrícola e florestal.

PALAVRAS-CHAVE: Biologia. Bioquímica. Ecologia. Criação massal. Taxonomia. Toxicologia.

\section{REFERENCES}

ALDRICH, J.; ZANUNCIO, J. C.; VILELA, E. F.; TORRES, J. B.; CAVE, R. D. Field tests of predaceous pentatomid pheromones and semiochemistry of Podisus and Supputius species (Hemiptera: Pentatomidae: Asopinae). Anais da Sociedade Entomológica do Brasil, Londrina, Londrina, v. 26, n. 1, p. 1-14, 1997. http://dx.doi.org/10.1590/S0301-80591997000100001

ARAÚJO, V. A.; LINO-NETO, J.; RAMALHO, F. S.; ZANUNCIO, J. C.; SERRÃO, J. E. (2011). Ultrastructure and heteromorphism of spermatozoa in five species of bugs (Pentatomidae: Heteroptera). Micron, Amsterdam, v. 42, n. 6, p. 560-567, 2011. http://dx.doi.org/10.1016/j.micron.2011.02.001

ARTOLA, J. A.; GARCIA, M. F.; DICINDIO, S. E. Bioecologia de Podisus nigrolimbatus, Spinola (Heteroptera, Pentatomidae), predator de Pyrrhalta luteola (Muller) (Coleoptera, Chrysomelidae). Idia, Buenos Aires, v. 401/404, p. 25-33, 1982.

ASSIS JR., S. L.; ZANUNCIO, T. V.; SANTOS, G. P.; ZANUNCIO, J. C. Efeito da suplementação de folhas de Eucalyptus urophylla no desenvolvimento e reprodução do predador Supputius cincticeps (Stal)

(Heteroptera: Pentatomidae). Anais da Sociedade Entomológica do Brasil, Londrina, v. 27, n. 2, p. 245-253, 1998. http://dx.doi.org/10.1590/S0301-80591998000200011

AZEVEDO, D. O.; ZANUNCIO, J. C.; ZANUNCIO, J. S.; MARTINS, G. F.; MARQUES-SILVA, S.; SOSSAI, M. F.; SERRÃO, J. E. Biochemical and morphological aspects of salivary glands of the predator Brontocoris tabidus (Heteroptera: Pentatomidae). Brazilian Archives of Biology and Technology, Curitiba, v. 50, n. 3, p. 469-477, 2007. http://dx.doi.org/10.1590/S1516-89132007000300013

AZEVEDO, F. R.; RAMALHO, F. S. Impacto da temperatura e da defesa da presa na utilização de Tenebrio molitor L. por ninfas do predador Supputius cincticeps (Heteroptera: Pentatomidae). Anais da Sociedade Entomológica do Brasil, Londrina, v. 28, n. 1, p. 111-119, 1999a. http://dx.doi.org/10.1590/S030180591999000100012

AZEVEDO, F. R.; RAMALHO, F. S. Efeitos da temperatura e defesa da presa no consumo pelo predador Supputius cincticeps (Stäl) (Heteroptera: Pentatomidae). Pesquisa Agropecuária Brasileira, Brasília, v. 34, n. 2, p. 165-171, 1999b. http://dx.doi.org/10.1590/S0100-204X1999000200003 
BATALHA, V. C.; ZANUNCIO, J. C.; PICANÇO, M. C.; SEDIYAMA, C. S. Seletividade de inseticidas aos predadores Podisus nigrispinus (Dallas, 1851) e Supputius cincticeps (Stal, 1860) (Heteroptera: Pentatomidae) e sua presa Lepidoptera. Revista Árvore, Viçosa, v. 19, n. 3, p. 382-395, 1995.

BERTI-FILHO, E. Biologia de Thyrinteina arnobia (Stoll, 1782) (Lepidoptera, Geometridae) e observações sobre a ocorrência de inimigos naturais. 1974. 74 f. Tese (Doutorado em Entomologia) -Escola Superior de Agronomia Luiz de Queiroz Universidade de São Paulo, Piracicaba, 1974.

BUCKUP, L. Os Pentatomídeos do Estado do Rio Grande do Sul (Hemiptera - Heteroptera - Pentatomidae). Iheringia - Série Zoologia, Porto Alegre, v. 16, p. 1-24, 1961.

BUCKUP, L. Pentatomídeos Neotropicais - II. Contribuição ao conhecimeto dos Asopinae da América do Sul (Hemiptera, Heteroptera - Pentatomidae). Iheringia - Série Zoologia, Porto Alegre, v. 15, p. 1-25, 1960.

BUCKUP, L. Notas entomológicas do Rio Grande do Sul. Lista Preliminar dos Pentatomideos do Rio Grande do Sul, com algumas informações zoogeográficas e ecológicas. Ciências e Letras, Porto Alegre, v. 4, n. 3, p. 46-61, 1952

CAMILO, S. S.; SOARES, M. A.; DOS SANTOS, J. B.; DE ASSIS JÚNIOR, S. L.; FERREIRA, E. A. \& MENEZES, C. W. G. Impactos toxicológicos de herbicidas recomendados para a cultura do milho em ninfas do predador Podisus nigrispinus (Hemiptera: Pentatomidae). Revista Brasileira de Herbicidas, Maringá, v. 11, n. 3, p. 339-346, 2012. http://dx.doi.org/10.7824/rbh.v11i3.189

CARVALHO, R. S.; VILELA, E. F.; BORGES, M.; ZANUNCIO, J. C. Comportamento de acasalamento do predador Podisus nigrispinus (Dallas) em laboratório. Anais da Sociedade Entomológica do Brasil, Londrina, v. 24, n. 1, p. 165-171, 1995. http://dx.doi.org/10.1603/EN12060

CARVALHO, R. S.; VILELA, E. F.; BORGES, M.; ZANUNCIO, J. C. Ritmo do comportamento de acasalamento e atividade sexual de Podisus connexivus Bergroth (Heteroptera: Pentatomidae: Asopinae). Anais da Sociedade Entomológica do Brasil, Londrina, v. 23, n. 2, p. 197-202, 1994a.

CARVALHO, R. S.; VILELA, E. F.; BORGES, M.; ALDRICH, J. R.; ZANUNCIO, J. C. Caracterização morfológica da glândula do feromônio sexual do predador Podisus nigrispinus (Dallas). Anais da Sociedade Entomológica do Brasil, Londrina, v. 3, n. 1, p. 143-147, 1994b.

CARVALHO, V. F. P.; VACARI, A. M.; POMARI, A. F.; DE BORTOLI, C. P.; RAMALHO, D. G.; DE BORTOLI, S. A. Interaction between the Predator Podisus nigrispinus (Hemiptera: Pentatomidae) and the Entomopathogenic Bacteria Bacillus thuringiensis. Environmental Entomology, Lanham, v. 41, n. 6, p. 1454$1461,2012$.

CASTRO, A. A.; CORRÊA, A. S.; LEGASPI, J. C.; GUEDES, R. N. C.; SERRÃO, J. E.; ZANUNCIO, J. C. (2013). Survival and behavior of the insecticide-exposed predators Podisus nigrispinus and Supputius cincticeps (Heteroptera: Pentatomidae). Chemosphere, Oxford, v. 93, n. 6, p. 1043-1050, 2013. http://dx.doi.org/10.1016/j.chemosphere.2013.05.075

CASTRO, A. A.; LACERDA, M. C.; ZANUNCIO, T. V.; RAMALHO, F. S.; POLANCZYK, R. A.; SERRÃO, J. E.; ZANUNCIO, J. C. Effect of the insect growth regulator diflubenzuron on the predator Podisus nigrispinus (Heteroptera: Pentatomidae). Ecotoxicology, Dordrecht, v. 21, n. 1, p. 96-103, 2012. http://dx.doi.org/10.1007/s10646-011-0769-z

CAVALCANTI, M. G.; VILELA, E. F.; EIRAS, A. E.; ZANUNCIO, J. C.; PICANCO, M. C. Interação tritrófica entre Podisus nigrispinus (Dallas) (Heteroptera: Pentatomidae), Eucalyptus e lagartas de Thyrinteina arnobia (Stoll) (Lepidoptera: Geometridae): visitação. Anais da Sociedade Entomológica do Brasil, Londrina, v. 29, n. 4, p. 697-703, 2000. http://dx.doi.org/10.1590/S0301-80592000000400009 
COELHO, R. R.; VEIGA, A. F. S. L.; TORRES, J. B. Preferência alimentar e desempenho de Brontocoris tabidus Signoret (Hemiptera, Pentatomidae) em plantas hospedeiras. Revista Brasileira de Entomologia, Curitiba, v. 53, n. 3, p. 475-481, 2009. http://dx.doi.org/10.1590/S0085-56262009000300025

CORACINI, M. D. A.; VILELA, E. F.; DE MARCO J. P.; ZANUNCIO, J. C.; FURTADO, M. Localização e aceitação de dieta artificial contendo feromônio sexual pelo predador Podisus nigrispinus (Dallas)

(Heteroptera: Pentatomidae). Anais da Sociedade Entomológica do Brasil, Londrina, v. 28, n. 4, p. 687-693, 1999. http://dx.doi.org/10.1590/S0301-80591999000400011

COSTA-LEITE, I. da, Sobre um Podisus (Hem. Pentatomidae) do Rio Grande do Sul. Memórias do Instituto Oswaldo Cruz, Rio de Janeiro, v. 55, n. 2, p. 209-210, 1957.

COSTA-LIMA, A. M. Insetos do Brasil: Hemípteros. $2^{\circ}$ Tomo. Escola Nacional de Agronomia, Série Didática, 1940. n. 3.352 p.

DA CUNHA, F. M.; CAETANO, F. H.; WANDERLEY-TEIXEIRA, V.; TORRES, J. B.; TEIXEIRA, A. A.; ALVES, L. C. Ultra-structure and histochemistry of digestive cells of Podisus nigrispinus (Hemiptera: Pentatomidae) fed with prey reared on bt-cotton. Micron, Amsterdam, v. 43, n. 2/3, p. 245-250, 2012. http://dx.doi.org/10.1016/j.micron.2011.08.006

DE BORTOLI, S. A.; OTUKA, A. K.; VACARI, A. M.; MARTINS, M. I. E. G.; VOLPE, H. X. L. Comparative biology and production costs of Podisus nigrispinus (Hemiptera: Pentatomidae) when fed different types of prey. Biological Control, Orlando, v. 58, n. 2, p. 127-132, 2011.

http://dx.doi.org/10.1016/j.biocontrol.2011.04.011

DIDONET, J.; ZANUNCIO, J. C.; SEDIYAMA, C. S.; PICANÇO, M. C. Desenvolvimento e sobrevivência ninfal de Podisus nigrispinus (Dallas) e Supputius cincticeps (Stål) (Heteroptera, Pentatomidae) em diferentes temperaturas. Revista Brasileira de Zoologia, Curitiba, v. 12, n. 3, p. 513-518, 1995. http://dx.doi.org/10.1590/s0101-81751995000300005

FERNANDES, L. G. Biologia e capacidade predatória de Podisus nigrolimbatus Spínola, 1832 e Podisus connexivus Bergroth, 1891 (Hemiptera: Pentatomidae: Asopinae) em condições de laboratório. 1990. 87f. Dissertação (Mestrado em Entomologia) Universidade Federal de Lavras, Lavras, 1990.

FERREIRA, J. A. M.; ZANUNCIO, J. C.; TORRES, J. B.; MOLINA-RUGAMA, A. J. Predatory behaviour of Podisus nigrispinus (Heteroptera: Pentatomidae) on different densities of Anticarsia gemmatalis (Lepidoptera: Noctuidae) larvae. Biocontrol Science and Technology, London, v. 18, n. 7, p. 711-719, 2008.

http://dx.doi.org/10.1080/09583150802271220

FIALHO, M. C. Q.; TERRA, W. R.; MOREIRA, N. R.; ZANUNCIO, J. C.; SERRÃO, J. E. Ultrastructure and immunolocalization of digestive enzymes in the midgut of Podisus nigrispinus (Heteroptera: Pentatomidae).

Arthropod Structure \& Development, Amsterdam, v. 42, n. 4, p. 277-285, 2013.

http://dx.doi.org/10.1016/j.asd.2013.03.002

FIALHO, M. C. Q. F.; ZANUNCIO, J. C.; NEVES, C. A.; RAMALHO, F. S.; SERRÃO, J. E. Ultrastructure of the Digestive Cells in the Midgut of the Predator Brontocoris tabidus (Heteroptera: Pentatomidae) After Different Feeding Periods on Prey and Plants. Annals of the Entomological Society of America, Lanham, v. 102, n. 1, p. 119-127, 2009. http://dx.doi.org/10.1603/008.102.0113

FRANÇA, I. W. B.; MARQUES, E. J.; TORRES, J. B.; OLIVEIRA, J. V. Efeitos de Metarhizium anisopliae (Metsch.) Sorok. e Beauveria bassiana (Bals.) Vuill. sobre o Percevejo Predador Podisus nigrispinus (Dallas) (Hemiptera: Pentatomidae). Neotropical Entomology, Londrina, v. 35, n. 3, p. 349-356, 2006. http://dx.doi.org/10.1590/S1519-566X2006000300009 
GONRING, A. H. R.; PICANÇO, M. C.; LEITE, G. L. D.; SUINAGA, F. A.; ZANUNCIO, J. C.. Seletividade de inseticidas a Podisus rostralis (Stal) (Heteroptera: Pentatomidae) predador de lagartas desfolhadoras de eucalipto. Revista Árvore, Viçosa, v. 27, n. 2, p. 263-268, 2003. http://dx.doi.org/10.1590/s010067622003000200015

GOULART, R. M.; VACARI, A. M.; DIBELLI, W.; DE BORTOLI, S. A. Efeito de Bacillus thuringiensis Berliner var. aizawai sobre a capacidade reprodutiva e sobrevivência de fêmeas do predador Podisus nigrispinus (Dallas, 1851) (Hemiptera: Pentatomidae). Horticultura Brasileira, Vitória da Conquista, v. 28, n. 2, p. S814-S821, 2010.

GRAZIA, J.; HILDEBRAND, R. Hemipteros Predadores de Insetos. In: I ENCONTRO SUL - BRASILEIRO DE CONTROLE BIOLÓGICO DE PRAGAS, 1987, Passu Fundo RS. Anais do I Encontro Sul-Brasileiro de Controle Biológico de Pragas. 1987. p. 21-37.

GRAZIA, J.; VECCHIO, M. D.; HILDEBRAND, R. Estudo das ninfas de heterópteros predadores: I - Podisus connexivus Bergroth, 1891 (Pentatomidae, Asopinae). Anais da Sociedade Entomológica do Brasil, Londrina, v. 14 , n. 2, p. 303-313, 1985.

GRAZIA, J.; VECCHIO, M. D.; BALESTIERI, F. M. P.; RAMIRO, Z. A. Estudo das ninfas de pentatomídeos (Heteroptera) que vivem sobre a soja (Glycine $\max ($ L.) Merrill): I - Euschistus heros (Fabricius, 1798) e Piezodorus guildinii (Westwood, 1837). Anais da Sociedade Entomológica do Brasil, Londrina, v. 9, n. 1, p. 39-51, 1980.

GROSMAN, A. H.; BREEMEN, M. V.; HOLTZ, A. M.; PALLINI, A.; RUGAMA, A. J. M.; PENGEL, H.; VENZON, M.; ZANUNCIO, J. C.; SABELIS, M. W.; JANSSEN, A. Searching behaviour of an omnivorous predator for novel and native host plants of its herbivores: a study on arthropod colonization of eucalyptus in Brazil. Entomologia Experimentalis et Applicata, Oxford, v. 116, n. 2, p. 135-142, 2005. http://dx.doi.org/10.1111/j.1570-7458.2005.00307.x

GUEDES, B. A. M.; ZANUNCIO, J. C.; RAMALHO, F. S.; SERRÃO, J. E. Midgut morphology and enzymes of the obligate zoophytophagous stinkbug Brontocoris tabidus (Signoret, 1863) (Heteroptera: Pentatomidae). Pan-Pacific Entomologist, Washington, v. 83, n. 1, p. 66-74, 2007. http://dx.doi.org/10.1111/j.15707458.2005.00307.x

GUEDES, R. N. C.; LIMA, J. O. G.; ZANUNCIO, J. C. Seletividade dos inseticidas, deltametrina, fenvalerato e fenitrotiom para Podisus connexivus Bergroth, 1891 (Heteroptera: Pentatomidae). Anais da Sociedade Entomológica do Brasil, Londrina, v. 21, n. 3, p. 339-346, 1992.

HOLTZ, A. M.; PALLINI, A.; VENZON, M.; ZANUNCIO, J. C.; PRATISSOLI, D.; BARBOSA, W. F.; ANDRADE, G. S. Antibiosis of Eucalyptus plants on Podisus nigrispinus. Phytoparasitica, Netherlands, v. 38, n. 1, p. 133-139, 2010. http://dx.doi.org/10.1007/s12600-010-0083-y

HOLTZ, A. M.; PALLINI, A.; ZANUNCIO, J. C.; PRATISSOLI, D.; MARINHO, J. S; PEREIRA, C. J.; DALVI, L. P. Resposta do predador Podisus nigrispinus (Heteroptera: Pentatomidae) à defesa induzida de planta por herbivoria. Magistra, Cruz das Almas, v. 20, n. 2, p. 161-166, 2008.

HOLTZ, A. M.; PRATISSOLI, D.; SAITO, N. S.; MELO, D. F.; POLANCZYK, R. A.; VIANNA, U. R. É possível à associação Podisus nigrispinus e espécies de Trichogramma em um programa de controle biológico em florestas? Idesia, Arica, v. 24, n. 2, p. 85-88, 2006a.

HOLTZ, A. M.; ZANUNCIO, J. C.; PRATISSOLI, D.; FERREIRA, R. A.; BELINELO, V. J.; MARINHO, J. S.; PEREIRA, C. J. Comportamento do predaor Podisus nigrispinus à plantas de Eucalyptus urophylla atacadas por Thyrinteina arnobia. Revista UNIVAP, São José dos Campos, v. 13, n. 1, p. 997-1000, 2006 b. 
LACERDA, M. C. Associação de produtos fitossanitários, cultivares transgênicas de soja tolerantes ao Glyphosate e organismos não alvo. 2008. 118 f. Tese (Doutorado em Fitotecnia). Universidade Federal de Viçosa, Viçosa, 2008.

LEMOS, W. P.; RIBEIRO, R. C.; RAMALHO, F. S.; SERRÃO, J. E.; ZANUNCIO, J. C. The reproductive tract of the males of the zoophytophagous predator Brontocoris tabidus (Signoret) (Heteroptera: Pentatomidae) with different diets and ages. American Journal of Agricultural and Biological Sciences, Vails Gate, v. 6, n. 1, p. 12-18, 2011.

LEMOS, W. P.; ZANUNCIO, V. V.; RAMALHO, F. S.; ZANUNCIO, J. C.; SERRÃO, J. E. Ovary histology of the predator Brontocoris tabidus (Hemiptera: Pentatomidae) of two ages fed on different diets.

Entomological News, Dover, v. 121, n. 3, p, 230-235, 2010a.

LEMOS, W. P.; ZANUNCIO, J. C.; LACERDA, M. C.; RIBEIRO, R. C.; SERRÃO, J. E. Morphology aspects of the fat body and the haemolymph of males of the predator Brontocoris tabidus (Het., Pentatomidae): Effect of the phytophagy and age. Journal of Agricultural and Biological Science, Islamabad, v. 5, n. 5, p. 32-40, $2010 b$.

LEMOS, W. P.; ZANUNCIO, J. C.; RAMALHO, F. S.; ZANUNCIO, V. V.; SERRÃO, J. E. Herbivory affects ovarian development in the zoophytophagous predator Brontocoris tabidus (Heteroptera, Pentatomidae).

Journal of Pest Science, Heidelberg, v. 83, n. 2, p. 69-76, 2010c. http://dx.doi.org/10.1007/s10340-009-0271-z

LEMOS, W. P.; SERRÃO, J. E.; ZANUNCIO, J. C.; LACERDA, M. C.; ZANUNCIO, V. V.; RIBEIRO, R. C. Body weight and protein content in the haemolymph of females of the zoophytophagous predator Brontocoris tabidus (Heteroptera: Pentatomidae) with different diets and ages. Journal of Plant Diseases and Protection, Stuttgart, v. 116, n. 5, p. 218-222, 2009a. http://dx.doi.org/10.1016/j.micron.2009.02.004

LEMOS, W. P.; ZANUNCIO, J. C.; RAMALHO, F. S.; SERRÃO, J. E. Fat body of the zoophytophagous predator Brontocoris tabidus (Het.: Pentatomidae) females: impact of the herbivory and age. Micron, Amsterdam, v. 40, n. 5-6, p. 635-638, 2009b. http://dx.doi.org/10.1163/157075606778441840

LEMOS, W. P.; RAMALHO, F. S.; SERRÃO, J. E.; ZANUNCIO, J. C.; BAUCE, E. Diet affects reproduction and number of oocytes per ovary of the predator Podisus nigrispinus (Dallas) (Heteroptera: Pentatomidae). Animal Biology. Koninklijke Brill NV, v. 56, n. 3, p. 279-287, 2006. http://dx.doi.org/10.1590/s151689132005000100017

LEMOS, W. P.; RAMALHO, F. S.; SERRÃO, J. E.; ZANUNCIO, J. C. Morphology of female reproductive tract of the predator Podisus nigrispinus (Dallas) (Heteroptera: Pentatomidae) fed on diferent diets. Brazilian Archives of Biology and Technology, Curitiba, v. 48, n. 1, p. 129-138, $2005 \mathrm{a}$.

LEMOS, W. P.; SERRÃO, J. E.; RAMALHO, F. S.; ZANUNCIO, J. C.; LACERDA, M. C. Effect of diet on male reproductive tract of Podisus nigrispinus (Heteroptera: Pentatomidae). Brazilian Journal of Biology, São Carlos, v. 65, n. 1, p. 91-96, 2005b. http://dx.doi.org/10.1590/S1519-69842005000100012

LEMOS, W. P.; MEDEIROS, R. S.; ZANUNCIO, J. C.; SERRÃO, J. E. Effect of sub-lethal concentrations of permethrin on ovary activation in the predator Supputius cincticeps (Heteroptera: Pentatomidae). Brazilian Journal of Biology, São Carlos, v. 65, n. 2, p. 287-290, 2005c. http://dx.doi.org/10.1590/s151969842005000200012

LEMOS, W. P.; ZANUNCIO, J. C.; SERRÃO, J. E. Attack behavior of Podisus rostralis (Heteroptera: Pentatomidae) adults on caterpillars of Bombyx mori (Lepidoptera: Bombycidae). Brazilian Archives of Biology and Technology, Curitiba, v. 48, n. 6, p. 975-981, 2005b. http://dx.doi.org/10.1590/S151689132005000800014 
LIMA, A. M. da C. Entomófagos Sul Americanos (parasitas e predadores) de insetos nocivos a agricultura. Boletim da Sociedade Brasileira de Agronomia, Rio de Janeiro, v. 11, n. 1, p. 1-33, 1948.

MAGALHÃES, L. C.; GUEDES, R. N.; OLIVEIRA, E. E.; TUELHER, E. S. Desenvolvimento e Reprodução do predador Podisus distinctus (Stal) (Heteroptera: Pentatomidae) frente a doses subletais de permetrina, Neotropical Entomology, Londrina, v. 31, n. 3, p. 445-448, 2002. http://dx.doi.org/10.1590/S1519566X2002000300015

MATOS-NETO, F. C.; OLIVEIRA, H. N.; ZANUNCIO, J. C.; HOLTZ, A. M.; OLIVEIRA, I.; FIALHO, M. C. Q. Ganancia de peso del depredador Podisus distinctus Heteroptera: Pentatomidae en combinaciones de las presas Tenebrio molitor Coleoptera: Tenebrionidae y Musca domestica Diptera: Muscidae. Revista de Biologia Tropical, San José, v. 52, n. 1, p. 101-108, 2004. http://dx.doi.org/10.15517/rbt.v52i1.14757

MEDEIROS, R. S.; SILVA, A. M. C.; ZANUNCIO, J. C.; RAMALHO, F. S.; SERRÃO, J. E.; CECON, P. R. Oviposition pattern of the predator Podisus nigrispinus (Heteroptera: Pentatomidae) under different temperatures. Biocontrol Science and Technology, London, v. 14, n. 5, p. 487-498, 2004.

http://dx.doi.org/10.1080/09583150410001682241

MEDEIROS, R. S.; RAMALHO, F. S.; SERRÃO, J. E.; ZANUNCIO, J. C. Temperature influence on the reproduction of Podisus nigrispinus, a predator of the Noctuidae larva Alabama argillacea. Journal of Applied Entomology, Berlin, v. 48, n. 6, p. 695-704, 2003.

MEDEIROS, R. S.; RAMALHO, F. S.; ZANUNCIO, J. C.; SERRÃO, J. E. Effect of temperature on life table parameters of Podisus nigrispinus (Het., Pentatomidae) fed with Alabama argillacea (Lep., Noctuidae) larvae. Journal of Applied Entomology, Berlin, v. 127, n. 1, p. 209-213, 2003b. http://dx.doi.org/10.1046/j.14390418.2003.00728.x

MENDONÇA, F. A. C.; BARRETO, M. R.; ASSIS JR., S.; MARSARO JR., A. L. Comportamento de corte e cópula do predador Supputius cincticeps (Stal) (Heteroptera: Pentatomidae) em laboratório. Anais da Sociedade Entomológica do Brasil, Londrina, v. 26, n. 1, p. 209-2012, 1997. http://dx.doi.org/10.1590/S030180591997000100030

MENEZES, C. W. G.; DOS SANTOS, J. B.; DE ASSIS JÚNIOR, S. L.; FONSECA A. J.; FRANÇA, A. C.; SOARES, M. A.; FERNANDES, A. F. Seletividade de atrazine e nicossulfurom a Podisus nigrispinus (Heteroptera: Pentatomidae). Planta Daninha, Viçosa, v. 30, n. 2, p. 327-334, 2012.

MENEZES, C. W. G.; SOARES, M. A.; DE ASSIS JÚNIOR, S. L.; MENEZES, S. J. M. C.; DOS SANTOS, J. B.; ZANUNCIO, J. C. Brontocoris tabidus (Heteroptera: Pentatomidae) preying on Podalia walker (Lepidoptera: Megalopygidae) on eucalypt plants in Brazil. Florida Entomologist, Lutz, v. 96, n. 1, p. 261263, 2013.

MOLINA-RUGAMA, A. J.; ZANUNCIO, J. C.; PRATISSOLI, D.; CRUZ, I. Efeito do intervalo de alimentação na reprodução e na longevidade do predador Podisus nigrispinus (Dallas) (Heteroptera: Pentatomidae). Anais da Sociedade Entomológica do Brasil, Londrina, v. 27, n. 1, p. 77-84, 1998. http://dx.doi.org/10.1590/S0301-80591998000100010

MORAES, G. J., MACEDO, N., SAGLIETTI, J. F. A. Biologia de Podisus sp. (Pentatomidae: Asopinae). In: CONGRESSO BRASILEIRO DE ENTOMOLOGIA, 3. Sociedade Entomológica do Brasil, Londrina, 1976. p. 43-44. (1976).

MOREIRA, L. A.; ZANUNCIO, J. C.; PICANÇO, M. C.; GUEDES, R. N. C. Effect of Eucalyptus feeding in the development, survival and reproduction of Tynacantha marginata (Heteroptera: Pentatomidae). Revista de Biología Tropical, San José, v. 44/45, n. 3/1, p. 253-257, 1997. 
MOREIRA, L. A.; ZANUNCIO, T. V.; ZANUNCIO, J. C.; PICANÇO, M. C. Aspectos biomorfológicos de Tynacantha marginata Dallas (Heteroptera: Pentatomidae) alimentado com larvas de Tenebrio molitor (Coleoptera: Tenebrionidae). Anais da Sociedade Entomológica do Brasil, Londrina, v. 25, n. 1, p. 125-130, 1996.

MOREIRA, L. A.; ZANUNCIO, J. C.; PICANÇO, M. C.; BRUCKNER, C. H. Tabelas de fertilidade e de esperança de vida de Tynacantha marginata (Heteroptera, Pentatomidae) alimentado com larvas de Tenebrio molitor L. (Coleoptera, Tenebrionidae) e folhas de Eucalyptus urophylla S.T. Blake. Revista Brasileira de Zoologia, Curitiba, v. 12, n. 2, p. 255-261, 1995. http://dx.doi.org/10.1590/S0101-81751995000200005

NEVES, R. C. S.; TORRES, J. B.; VIVAN, L. M. Reproduction and dispersal of wing-clipped predatory stinkbugs, Podisus nigrispinus in cotton fields. BioControl, Dordrecht, v. 54, n. 1, p. 9-17, 2009. http://dx.doi.org/10.1007/s10526-008-9150-4

OLIVEIRA, J. E. M.; DE BORTOLI, S. A.; MIRANDA, J. M.; TORRES, J. B.; ZANUNCIO, J. C. Predação por Podisus nigrispinus (Heteroptera: Pentatomidae) sob efeito da densidade de Alabama argillacea (Lepidoptera: Noctuidae) e idades do algodoeiro. Científica, Jaboticabal, v. 36, n. 1, p. 1-9, 2008.

OLIVEIRA, J. A.; OLIVEIRA, M. G. A.; GUEDES, R. N. C.; SOARES, M. J. Morphology and preliminary enzyme characterization of the salivary glands from the predatory bug Podisus nigrispinus (Heteroptera: Pentatomidae). Bulletin of Entomological Research, Cambridge, v. 98, n. 3, p. 251-258, 2006. http://dx.doi.org/10.1079/BER2006420

OLIVEIRA, J. E. M.; TORRES, J. B.; CARRANO-MOREIRA, A. F.; RAMALHO, F. S. Biologia de Podisus nigrispinus predando lagartas de Alabama argillacea em campo. Pesquisa Agropecuária Brasileira, Brasília, v. 37, n. 1, p. 7-14, 2002. http://dx.doi.org/10.1590/S0100-204X2002000100002

OLIVEIRA, J. E. M.; TORRES, J. B.; MOREIRA, A. F. C.; ZANUNCIO, J. C. Efeito da densidade de presas e do acasalamento na taxa de predação de fêmeas de Podisus nigrispinus (Dallas) (Heteroptera: Pentatomidae) em condições de laboratório e campo. Neotropical Entomology, Londrina, v. 30, n. 4, p. 647-654, 2001. http://dx.doi.org/10.1590/S1519-566X2001000400020

OTUKA, A. K.; VACARI, A. M.; MARTINS, M. I. E. G.; DE BORTOLI, S. A. Custo de produção de Podisus nigrispinus (Dallas, 1851) (Hemiptera: Pentatomidae) criado com diferentes presas. O Biológico, São Paulo, v. 68 , n. $1 / 2$, p. 224-227, 2006.

PELÚZIO, R. J. E. Duração ninfal, um critério de seleção de Podisus nigrispinus (Heteroptera: Pentatomidae) com maior potencial reprodutivo e capacidade de consumo? 2012. $63 \mathrm{f}$. Tese (Doutorado em Fitotecnia) Universidade Federal de Viçosa, Viçosa, 2012.

PEREIRA, A. I. A.; RAMALHO, F. S.; BANDEIRA, C. M.; MALAQUIAS, J. B.; ZANUNCIO, J. C. Agedependent fecundity of Podisus nigrispinus (Dallas) (Heteroptera: Pentatomidae) with sublethal doses of gammacyhalothrin. Brazilian Archives of Biology and Technology, Curitiba, v. 52, n. 5, p. 1157-1166, 2009. http://dx.doi.org/10.1590/s1516-89132009000500013

PEREIRA, A. I. A.; RAMALHO, F. S.; MALAQUIA, J. B.; BANDEIRA, C. M.; SILVA, J. P. S.; ZANUNCIO, J. C. Density of Alabama argillacea larvae affects food extraction by females of Podisus nigrispinus. Phytoparasitica, Netherlands, v. 36, n. 1, p. 84-94, 2008. http://dx.doi.org/10.1007/BF02980751

PICANÇO, M. C.; RIBEIRO, L. J.; LEITE, G. L. D.; ZANUNCIO, J. C. Seletividade de inseticidas a Podisus nigrispinus predador de Ascia monustes orseis. Pesquisa Agropecuária Brasileira, Brasília, v. 32, n. 4, p. 369-372, 1997.

PIRES, E. M. Dispersão e predação de Asopinae associados a eucaliptocultura. 2010. 84 f. Tese (Doutorado em Entomologia). Universidade Federal de Viçosa, Viçosa, 2010. 
PIRES, E. M.; ZANUNCIO, J. C.; SERRÃO, J. E. Cannibalism of Brontocoris tabidus and Podisus nigrispinus (Heteroptera: Pentatomidae) on periods of pre-release without food or fed with Eucalyptus cloeziana plants. Phytoparasitica, Netherlands, v. 39, n. 1, p. 27-34, 2010a. http://dx.doi.org/10.1007/s12600-010-0132-6

PIRES, E. M.; PINTO, R.; SANTOS, G. P.; SOARES, M. A.; ZANUNCIO, T. V.; ZANUNCIO, J. C. Produção de percevejos predadores. Visconde do Rio Branco: ed. Epamig, 2009a. 85 p.

PIRES, E. M.; AZEVEDO, D. O.; LIMA, E. R.; PELÚZIO, R. J. E.; SERRÃO, J. E.; ZANUNCIO, J. C. Desenvolvimento, reprodução e performance predatória do percevejo zoofitófago Podisus distinctus (Hemiptera: Pentatomidae) alimentado com larvas de Musca domestica (Diptera: Muscidae) imobilizadas ou soltas. Revista Brasileira de Biociências, Porto Alegre, v. 7, n. 3, p. 280-284, 2009b.

PIRES, E. M.; PINTO, R.; LACERDA, M. C.; ZANUNCIO, J. C.; FIALHO, M. C. Q. Potencial reprodutivo horário do predador de lagartas desfolhadoras do eucalipto: Podisus nigrispinus (Heteroptera: Pentatomidae). Revista Árvore, Viçosa, v. 30, n. 6, p. 1039-1044, 2006. http://dx.doi.org/10.1590/s0100-67622006000600020

RODRIGUES, A. R. S.; SERRÃO, J. E.; TEIXEIRA, V. W.; TORRES, J. B.; TEIXEIRA, A. A.

Spermatogenesis, changes reproductive structures, and time constraint associated with inseminations in Podisus nigrispinus. Journal of Insect Physiology, New York, v. 54, n. 12, p. 1543-1551, 2008.

http://dx.doi.org/10.1016/j.jinsphys.2008.09.003

SÁ, V. G. M.; ZANUNCIO, J. C.; SOARES, M. A.; ROSA, C. S.; SERRÃO, J. E. Morphology and postdepositional dynamics of eggs of the predator Podisus distinctus (Stal) (Heteroptera: Pentatomidae: Asopinae). Zootaxa, New Zeland, v. 3641, n. 3, p. 282-288, 2013.

SAAVEDRA, J. L. D.; ZANUNCIO, J. C.; TORRES, J. B.; VINHA, E. Response of Podisus nigrispinus (Dallas, 1851) (Heteroptera: Pentatomidae) nymphs to prey and artificial diets. Cientifica, Jaboticabal, v. 29, n. 1/2, p. 19-32, 2001.

SAAVEDRA, J. L. D.; ZANUNCIO, J. C.; ZANUNCIO, T. V.; CANTOR, F. Dieta artificial con carne de res, hojas de mora (Morus alba), sales de Wesson y yema de huevo de gllina para Podisus nigrispinus (Hemiptera: Pentatomidae). Revista Colombiana de Entomologia, Bogotá, v. 24, n. 1/2, p. 13-16, 1999.

SAAVEDRA, J. L. D.; ZANUNCIO, J. C.; ZANUNCIO, T. V.; GUEDES, R. N. C. Prey capture ability of Podisus nigrispinus (Dallas) (Heteroptera: Pentatomidae) reared for successive generations on meridic diets. Journal of Applied Entomology, Berlin, v. 121, n. 1/5, p. 327-330, 1997. http://dx.doi.org/10.1111/j.14390418.1997.tb01414.x

SAAVEDRA, J. L. D.; ZANUNCIO, J. C.; GUEDES, R. N. C.; DE CLERCQ, P. Continuous rearing of Podisus nigrispinus (Dallas) (Heteroptera: Pentatomidae) on an artificial diet. Mededelingen Faculteit Landbouwkundige en Toegepaste Biologische Wetenschappen Universiteit Gent, Gante, v. 61, n. 3A, p. 767-772, 1996.

SAAVEDRA, J. L. D.; ZANUNCIO, J. C.; VILELA, E. F.; SEDIYAMA, C. S.; DE CLERCQ, P. Development of Podisus nigrispinus (Dallas) (Heteroptera: Pentatomidae) on meat-based artificial diets. Mededelingen Faculteit Landbouwkundige en Toegepaste Biologische Wetenschappen Universiteit Gent, Gante, v. 60, n. 3A, p. 683-688, 1995.

SAAVEDRA, J. L. D. Dieta artificial para Podisus nigrispinus (Dallas) e influência na sua capacidade de predação de Anticarsia gemmatalis Hubner. 1995. 128 f. Tese (Doutorado em Fitotecnia) - Universidade Federal de Viçosa, Viçosa, 1995. 
SAAVEDRA, J. L. D.; ZANUNCIO, J. C.; DELLA LUCIA, T. M. C.; REIS, F. P. Effect of artificial diet on fecundity and fertility of the predator Podisus connexivus Bergroth, 1891 (Hemiptera: Pentatomidae). Anais da Sociedade Entomológica do Brasil, Londrina, v. 21, n. 2, p. 69-76, 1992a.

SAAVEDRA, J. L. D.; ZANUNCIO, J. C.; DELLA LUCIA, T. M. C.; VILELA, E. F. Dieta artificial para la crianza de Podisus connexivus (Hemiptera: Pentatomidae). Turrialba, San José, v. 42, n. 2, p. 258-261, 1992 b.

SANTOS, G. P.; ZANUNCIO, T. V.; RIBEIRO, G. T.; SILVA, E. P.; ZANUNCIO, J. C. Influência da temperatura no desenvolvimento ninfal de Podisus distinctus (Dallas) (Heteroptera: Pentatomidae). Revista Cerne, Viçosa, v. 10, n. 2, p. 213-221, 2005. http://dx.doi.org/10.1590/S0085-56262012005000031

SILVA, R. B.; CORRÊA, A. S.; DELLA-LUCIA, T. M. C.; PEREIRA, A. I. A.; CRUZ, I.; ZANUNCIO, J. C. Does the aggressiveness of the prey modify the attack behavior of the predator Supputius cincticeps (Stal) (Hemiptera, Pentatomidae)? Revista Brasileira de Entomologia, Curitiba, v. 56, n. 2, p. 244-248, 2012.

SILVA, A. G. A. Notas sobre Podisus nigrolimbatus (Spinola, 1852) (Pentatomidae: Asopinae). Boletim da Sociedade Cearense de Agronomia, Fortaleza, v. 6, p. 27-28, 1965.

SILVA, A. G. A. Contribuição para o estudo da biologia de três pentatomídeos: o possível emprego destes insetos no combate biológico de espécies nocivas. O Campo, v. 43, p. 23-25, 1933.

SOARES, M. A.; BATISTA, J. D.; ZANUNCIO, J. C.; LINO NETO, J.; SERRÃO, J. E. Ovary development, egg production and oviposition for mated and virgin females of the predator Podisus nigrispinus (Heteroptera: Pentatomidae). Acta Scientiarum. Agronomy, Maringá, v. 33, n. 4, p. 597-602, 2011.

http://dx.doi.org/10.4025/actasciagron.v33i4.6694

SOARES, M. A. Interações entre o predador Podisus nigrispinus (Heteroptera: Pentatomidae) e o parasitoide Palmistichus elaeisis (Hymenoptera: Eulophidae). 1010. 105 f. Tese (Doutorado em Entomologia) Universidade Federal de Viçosa, Viçosa, 2010.

SOARES, M. A.; ZANUNCIO, J. C.; LEITE, G. L. D.; WERMELINGER E. D.; SERRÃO, J. E. Does Thyrinteina arnobia (Lepidoptera: Geometridae) use different defense behaviours against predators? Journal of Plant Diseases and Protection, Stuttgart, v. 116, n. 1, p. 30-33, 2009.

SUINAGA, F., PICANÇO, M. C., ZANUNCIO, J. C.; BASTOS, C. Seletividade fisiológica de inseticidas para Podisus nigrispinus (Dallas, 1851) (Heteroptera: Pentatomidae), predador de lagartas desfolhadoras de eucalipto. Revista Árvore, Viçosa, v. 20, n. 3, p. 407-414, 1996.

TELLA, R. Dados bionômicos de um percevejo predador. Bragantia, Campinas, v. 11, n. 4/6, p. 179-180, 1951. http://dx.doi.org/10.1590/s0006-87051951000200009

THOMAS, D. B. Taxonomic synopsis of the Asopinae Pentatomidae (Heteroptera) of the Western Hemisfere. Lanham: Entomological Society of 12 America, 1992. 156 p.

TORRES, J. B. Insecticide Resistance in Natural Enemies - Seeking for Integration of Chemical and Biological Controls. Journal of Biofertilizers and Biopesticides, Sunnyvale, v. 3, n. 3, p. 55-72, 2012. http://dx.doi.org/10.4172/2155-6202.1000e104

TORRES, J. B.; BOYD JR, D. W. Zoophytophagy in predatory Hemiptera. Brazilian Archives of Biology and Technology, Curitiba, v. 52, n. 5, p. 1199-1208, 2009. http://dx.doi.org/10.1590/S1516-89132009000500018

TORRES, J. B.; RUBERSON, J. R. Interactions of Bacillus thuringiensis Cry1Ac toxin in genetically engineered cotton with predatory heteropterans. Transgenic Research, Netherlands, v. 17, n. 3, p. 345-354, 2008. http://dx.doi.org/10.1007/s11248-007-9109-8 
TORRES, J. B.; ZANUNCIO, J. C.; MOURA, M. A. The predatory stinkbug Podisus nigrispinus: biology, ecology and augmentative releases for lepidopteran larval control in Eucalyptus forests in Brazil. Perspectives in Agriculture, Veterinary Sciences, Nutrition and Natural Resources, Wallingford, v. 15, n. 1, p.1-18, 2006a.

TORRES, J. B.; RUBERSON, J. R.; ADANG, M. J. Expression of Bacillus thuringiensis Cry1Ac protein in cotton plants, acquisition by pests and predators: a tritrophic analysis. Agricultural and Forest Entomology, Oxford, v. 8, n. 3, p. 191-202, 2006b. http://dx.doi.org/10.1111/j.1461-9563.2006.00298.x

TORRES, J. B.; RUBERSON, J. R. Toxicity of thiamethoxam and imidacloprid to Podisus nigrispinus (Dallas) (Heteroptera: Pentatomidae) nymphs associated to aphid and whitefly control in cotton. Neotropical Entomology, Londrina, v. 33, n. 1, p. 99-106, 2004. http://dx.doi.org/10.1590/s1519-566x2004000100017

TORRES, J. B.; SILVA-TORRES, C. S.; BARROS, R. Relative effects of the insecticide thiamethoxam on the predator Podisus nigrispinus and the tobacco whitefly Bemisia tabaci in nectaried and nectariless cotton. Pest Management Science, Chichester, v. 59, n. 3, p. 315-23, 2003. http://dx.doi.org/10.1002/ps.640

TORRES, J. B.; EVANGELISTA JUNIOR., W. S.; BARROS, R.; GUEDES, R. N. C. Dispersal of Podisus nigrispinus (Het., Pentatomidae) nymphs preying on tomato leafminer: effect of predator release time, density and satiation level Journal of Applied Entomology, Berlin, v. 126, n. 6, p. 326-332, 2002.

TORRES, J. B.; DE CLERCQ, P.; BARROS, R. Effect of spinosad on the predator Podisus nigrispinus and its lepidopterous prey. Mededelingen Faculteit Landbouwkundige en Toegepaste Biologische Wetenschappen Universiteit Gent, Gante, v. 64, n. 3A, p. 211-218, 1999.

TORRES, J. B.; ZANUNCIO, J. C.; OLIVEIRA, H. N. Nymphal development and adult reproduction of the stinkbug predator Podisus nigrispinus (Het., Pentatomidae) under fluctuating temperatures. Journal of Applied Entomology, Berlin, v. 122, n. 4, p. 509-514, 1998. http://dx.doi.org/10.1111/j.1439-0418.1998.tb01536.x

TORRES, J. B.; ZANUNCIO, J. C.; SAAVEDRA, J. L. D.; ALDRICH, J. Extrato da glândula de feromônio na atração e estimulação alimentar de Podisus nigrispinus (Dallas) e Supputius cincticeps (Stal). Anais da

Sociedade Entomológica do Brasil, Londrina, v. 26, n. 3, p. 463-469, 1997a. http://dx.doi.org/10.1590/S030180591997000300008

TORRES, J. B.; PRATISSOLI, D.; ZANUNCIO, J. C. Exigências térmicas e potencial de desenvolvimento dos parasitóides Telenomus podisi Ashmead e Trissolcus brochymenae (Ashmead) em ovos do percevejo predador Podisus nigrispinus (Dallas). Anais da Sociedade Entomológica do Brasil, Londrina, v. 26, n. 3, p. 445-453, 1997b. http://dx.doi.org/10.1590/S0301-80591997000300006

VACARI, A. M.; DE BORTOLI, S. A.; TORRES, J. B. Relationship between the predatory behavior of Podisus nigrispinus and developmental phase and density of its prey, Plutella xylostella. Entomologia Experimentalis et Applicata, Oxford, v. 145, n. 1, p. 30-37, 2012.

VACARI, A. M.; GOULART, R. M.; VIANA, C. L. T. P.; LAURENTIS, V. L.; THULER, R. T.; DE BORTOLI, S. A. Tabelas de vida de Podisus nigrispinus (Dallas, 1851) (Hemiptera: Pentatomidae) alimentado com pupas de Plutella xylostella (Linnaeus, 1758) (Lepidoptera: Plutellidae) em laboratório. Horticultura Brasileira, Vitória da Conquista, v. 27, n. 2, p. S3524-S3529, 2009. http://dx.doi.org/10.1111/j.15707458.2012.01310.x

VACARI, A. M.; OTUKA, A. K.; DE BORTOLI, S. A. Desenvolvimento de Podisus nigrispinus (Dallas, 1851) (Hemiptera: Pentatomidae) alimentado com lagartas de Diatraea saccharalis (Fabricius, 1794) (Lepidoptera: Crambidae). Arquivos do Instituto Biológico, São Paulo, v. 74, n. 3, p. 259-265, 2007. 
VACARI, A. M.; ALBERGARIA, N. M. M. S.; OTUKA, A. K.; DÓRIA, H.; LOUREIRO, E.; DE BORTOLI, S. A. Seletividade de óleo de nim (Azadirachta indica A. Juss) sobre Podisus nigrispinus (Dallas, 1851) (Heteroptera: Pentatomidae). Arquivos do Instituto Biológico, São Paulo, v. 71, n. 4, p. 190-194, 2004.

VIVIAN, L. M.; TORRES, J. B.; VEIGA, A. F. S. L.; ZANUNCIO, J. C. Comportamento de predação e conversão alimentar de Podisus nigrispinus sobre a traça-do-tomateiro. Pesquisa Agropecuária Brasileira. Brasília, v. 37, n. 5, p. 581-587, 2002.

ZANUNCIO, J. C.; JUSSELINO-FILHO, P.; RIBEIRO, R. C.; CASTRO, A. A.; ZANUNCIO, T. V.; SERRÃO, J. E. Fertility and life expectancy of a predatory stinkbug to sublethal doses of a pyrethroid. Bulletin of Environmental Contamination and Toxicology, New York, v. 90, n. 1, p. 39-45, 2013.

http://dx.doi.org/10.1007/s00128-012-0883-5

ZANUNCIO, J. C.; FERREIRA, A. M. R. M.; TAVARES, W. S.; TORRES, J. B.; SERRÃO, J. E.; ZANUNCIO, T. V. Rearing the predator Brontocoris tabidus (Heteroptera: Pentatomidae) with Tenebrio molitor (Coleoptera: Tenebrionidae) pupa on Eucalyptus grandis in the field. American Journal of Plant Sciences, Washington, v. 2, n. 3, p. 282-288, 2011a.

ZANUNCIO, J. C.; JUSSELINO-FILHO, P.; RIBEIRO, R. C.; ZANUNCIO, T. V.; RAMALHO, F. S.; SERRÃO, J. E. Hormetic responses of a stinkbug predator to sublethal doses of pyrethroid. Bulletin of Environmental Contamination and Toxicology, New York, v. 87, n. 6, p. 608-614, 2011 b. http://dx.doi.org/10.1007/s00128-011-0405-x

ZANUNCIO, J. C.; SILVA, C. A. D.; LIMA, E. R.; PEREIRA, F. F.; RAMALHO, F. S.; SERRÃO, J. E. Predation rate of Spodoptera frugiperda (Lepidoptera: Noctuidae) larvae with and without defense by Podisus nigrispinus (Heteroptera: Pentatomidae). Brazilian Archives of Biology and Technology, Curitiba, v. 51, n. 1, p. 121-125, 2008. http://dx.doi.org/10.1590/S1516-89132008000100015

ZANUNCIO, J. C.; LEMOS, W. P.; LACERDA, M. C.; ZANUNCIO, T. V.; SERRÃO, J. E.; BAUCE, E. Agedependent fecundity and fertility life tables of the predator Brontocoris tabidus (Heteroptera: Pentatomidae) under field conditions. Journal of Economic Entomology, Riverside, v. 99, n. 2, p. 401-407, 2006. http://dx.doi.org/10.1093/jee/99.2.401

ZANUNCIO, T. V.; ZANUNCIO, J. C.; SERRÃO, J. E.; MEDEIROS, R. S.; PINON, T. B.; SEDYIAMA, C. A. Fertility and life expectancy of the predator Supputius cincticeps (Heteroptera: Pentatomidae) exposed to sublethal doses of permethrin. Biological Research, Santiago, v. 38, n. 1, p. 31-39, 2005.

http://dx.doi.org/10.4067/s0716-97602005000100005

ZANUNCIO, T. V.; SERRÃO, J. E.; ZANUNCIO, J. C.; GUEDES, R. N. C. Permethrin-induced hormesis on the predator Supputius cincticeps (Stal, 1860) (Heteroptera: Pentatomidae). Crop Protection, New York, v. 22, n. 7, p. 941-947, 2003. http://dx.doi.org/10.1016/S0261-2194(03)00094-2

ZANUNCIO, J. C.; MOLINA-RUGAMA, A. J.; SERRÃO, J. E.; PRATISSOLI, D. Nymphal development and reproduction of Podisus nigrispinus (Heteroptera: Pentatomidae) fed with combinations of Tenebrio molitor (Coleoptera: Tenebrionidae) pupae and Musca domestica (Diptera: Muscidae) larvae. Biocontrol Science and Technology, London, v. 11, n. 3, p. 331-337, 2001. http://dx.doi.org/10.1080/09583150120055736

ZANUNCIO, J. C.; OLIVEIRA, H. N.; TORRES, J. B.; PRATISSOLI, D. Egg parasitoids of Podisus sculptus Distant (Heteroptera: Pentatomidae) in an Eucalyptus plantation in the Brazilian Amazonian Region. Revista de Biologia Tropical, San José, v. 48, n. 4, p. 989-992, 2000. http://dx.doi.org/10.1111/j.1439-

0418.1998.tb01526.x

ZANUNCIO, J. C.; BATALHA, V. C.; GUEDES, R. N. C.; PICANÇO, M. C. Insecticide selectivity to Supputius cincticeps (Stal) (Het.: Pentatomidae) and its prey Spodoptera frugiperada (J.E. Smith) (Lep.: Noctuidae). Journal of Applied Entomology, Berlin, v. 122, n. 3, p. 457-460, 1998. 
ZANUNCIO, J. C.; SAAVEDRA, J. L. D.; OLIVEIRA, H. N.; DEGHEELE, D.; DE CLERCQ P.

Development of the predatory stinkbug Brontocoris tabidus (Signoret) (Heteroptera: Pentatomidae) on different proportions of an artificial diet and pupae of Tenebrio molitor L. (Coleoptera: Tenebrionidae). Biocontrol Science and Technology, London, v. 6, n. 4, p. 619-625, 1996. http://dx.doi.org/10.1080/09583159631253

ZANUNCIO, J. C.; LEITE, J. E. M.; SANTOS, G. P.; NASCIMENTO, E. C. Nova metodologia para criação em laboratório de hemípteros predadores. Revista Ceres, Viçosa, v. 41, p, 88-93, 1994a.

ZANUNCIO, J. C.; ALVES, J. B.; ZANUNCIO, T. V.; GARCIA, J. F. Hemipterous predators of eucalypt defoliator caterpillars. Forest Ecology and Management, Amsterdam, v. 65, n. 1, p. 65-73, 1994b.

http://dx.doi.org/10.1016/0378-1127(94)90258-5

ZANUNCIO, T. V.; ZANUNCIO, J. C.; BATALHA, V. C.; SANTOS, G. P. Efeito da alimentação com lagartas de Bombyx mori e larvas de Musca domestica no desenvolvimento de Podisus nigrolimbatus (Hemiptera: Pentatomidae). Revista Brasileira de Entomologia, Curitiba, v. 37, n. 2, p. 273-277, 1993a.

ZANUNCIO, J. C.; GUEDES, R. N. C.; GARCIA, J. F.; RODRIGUES, L. A Impact of two formulations of deltamethrin in aerial application against Eucalyptus caterpillars and theirs predaceos bugs. Mededelingen Faculteit Landbouwkundige en Toegepaste Biologische Wetenschappen Universiteit Gent, Gante, v. 58, n. 2, p. 477-481, 1993 b.

ZANUNCIO, J. C.; ALVES, J. B.; LEITE, J. E. M.; NASCIMENTO, C. E.; SARTORIO, R.C. Métodos para criação de hemipteros predadores de lagartas. Anais da Sociedade Entomológica do Brasil, Londrina, v. 21, n. 2, p. 245-251, 1992.

ZANUnCIO, T, V.; BATAlHA, V. C.; ZANUNCIO, J. C.; SANTOS, G. P. Parâmetros biológicos de Podisus connexivus (Hemiptera: Pentatomidae) em alimentação alternada com lagartas de Bombyx mori e larvas de Musca domestica. Revista Árvore, Viçosa, v. 15, n. 3, p. 308-315, 1991. 